sound. No one, nevertheless, ever seem; to have paid the smallest attention to his evolutionary theories. Even Silvestre, who pronounsed his éloge at a public meeting of the Société Royale d'Agriculture in I827, a bstains from the slightest reference to them.

While in his experiments and his mode of drawing conclusions from them Duchesne strongly recalls the method of Mr. Darwin, the parallel cannot be carried further. In so far as he obtained a glimpse at the molern doctrine of evolution it was in the form afterwards formulated by Lamarck. Of the part played by the struggle for existence in the matter I find no trace in his writings.

W. T. THISELTON DYER

\section{TEACHING ANIMALS TO CONVERSE}

MR. DARWIN'S notes on Instinct, recently published by my friend Mr. Romanes, have again called our attention to the interesting subject of instinct in animals.

Miss Martineau once remarked that, considering how long we have lived in close association with animals, it is astonishing how little we know about them, and especially about their mental condition. This applies with especial force to our domestic animals, and above all of course to doss.

I believe that it arises very much from the fact that hitherto we have tried to teach animals rather than to learn from them,-- to convey our ideas to them, rather than to devise any language, or code of signals, by means of which they might communicate theirs to us. No doubt the former process is interesting and instructive, but it doesinot carry us very far.

Under these circumstances it has occurred to me whether some such system as that followed with deafmutes, especially by Dr. Howe with Laura Bridgman, might not prove very instructive if adapted to the case of dings.

Accordingly I prepared some pieces of stout cardboard, and printed on each in legible letters a word such as "Food," "Bone," "Out," \&c. The head master of one of the deaf and dumb schools kindly agreed to assist me. We each began with a terrier puppy, but neither of us obtained any satisfactory results. My dog indeed was lost before I had had him long. I then began training a black poodle, "Van" by name, kindly given me by my friend Mr. Nickalls. I commenced by giving the dog food in a saucer, over which I laid the card on which was the word "Food," placing also by the side an empty saucer, covered b: a plain card.

"Van" syon learnt to distinguish between the two, and the next stage was to teach him to bring me the card; this he now does, and hands it to me quite prettily, and I then give him a bone, or a little fuod, or take him out, according to the card brought. He still brings sometimes a plain card, in which case I pint out his error, and he then takes it back and changes it. This however does not of ten happen. Yesterday morning, for in stance, "Van" brought me the card with "Food" on it, nine times in succession, selecting it from among other plain cards, though I changed the relative position every time.

No one who sees him can doubt that he understands the act of bringing the card with the word "Food" on it as a request for something to eat, and that he distinguishes between it and a plain card. I also believe that he distinguishes for instance between the card with the word "Food" on it and the card with "Out" on it.

This then seems to open up a method, which may be carried much further, for it is obvious that the cards may be multiplied, and the dog thus enabled to communicate freely with us. I have as yet, I know, made only a very small beginning, and hope to carry the experiment much further, but my object in sending this communication is $t w o f o l d$. In the first place I trust that some of the readers of NATURE may be able and willing to suggest extensions and improvements of the idea.

Secondly, my spare time is small and liable to many interruptions; animals also we know differ greatly from one another. Now many of your readers have favourite dogs, and I would express a hope that some of them may be disposed to study them in the manner indicated.

The observations, even though negative, would be interesting; but I confess I hope that some positive results might follow, which would enable us to obtain a more correct insight into the minds of animals than we have yet acquired.

High Elms, Down, Kent, December 20, I 883

\section{THE FRENCH DEEP-SEA EXPEDITION $O F$ I 883}

I HAVE just returned from a very short visit to Paris, made for the purpose of inspecting the Mollusca which were procured during last summer's deep-sea expedition in the French Government steamer Talisman. The expedition was under the scientific charge of Prof. Alphonse Milne-Edwards. For the opportunity of this inspection I was indebted to the kindness of my friend Dr. Paul Fischer, whose reputation as a conchologist is so well known.

The course of the expedition was along the Atlantic coasts of Spain, Marocco, Sahara, Senegal, Cape Verde Isles, the Canaries, and Azores; and the time occupied was three months. More full and accurate particulars will very shortly be given by Prof. A. Milne-Edwards to the Academy of Sciences, and be published in their Comptes Rendus. The collection will be exhibited next month to public view. The greatest depth explored was about 2200 fathoms. The trawl was mostly used. Life was plentiful everywhere. As was the case in the Porcupine, Challenger, and other expeditions of the same kind, many animals (especially Crustacea) at the greatest depths were highly and brightly coloured, some of them having large eyes, and others being blind or eyeless. There was an abundance of hitherto unknown forms (genera and species) in every department of zoologyfishes, Mollusca, Polyzua, Crustacea, Annelids, Ecbinoderms, Polyps, Corals, Foraminifera, and Sponges Among the Mollusca were some remarkable cases of the wide distribution of species in respect of space as well as of depth. For instance, boreal shells, such as Fusus islandicus and $F$. berniciensis, which inhabit northern seas at moderate depths, viz. 50 to 80 fathoms, were found living off the coast of Marocco, and the latter species even below the tropic of Capricorn, at depths of from 450 to 2200 fathoms. Lima excavata, considered a peculiarly Norwegian species, was likewise obtained off the Moorish coast, of a very large size; it was recorded by Prof. Seguenza as a Pliocene fossil of Sicily and Calabria, under the name of Lima gigantea. In the Porcupine Expedition of 1870 fragments were dredged off Cape St. Vincent; and in the Challenger Expedition this fine species was obtained from io to 175 fathoms off Western Patagonia and Japan. A bivalve (Scrobicularia longicallus), which in northern seas inhabits moderate depths, was procured in many places by the Talisman, at depths varying from 350 to 1429 fathoms. It occurred living in the deepest dredgings of the Porupine Expedition of 1869 , off the coast of Brittany, at a depth of 2435 fathoms. Many Mollusca (e.g. Pecten vitreus, Limopsis minuta, Dentalium agile, Trochus ottoi, Columbella haliceti, and Scaphander punctostriatus) seem to inhabit the depths of the North Atlantic in every part, from one side to the other. The smaller shells in the Talisman collection have not yet been picked out. The Marquis de Folin will, with his usual care and industry, undertake that part of the work, which will occupy some time; he has requested me to examine and name those species which 